Environment Conservation Journal 14(1\&2) 87-91, 2013

ISSN 0972-3099 (Print) 2278-5124 (Online)

Abstracted and Indexed

\title{
Effect of cold stress on biochemical constituents of fresh water fish Ophiocephalus unmourilius
}

\author{
Anand S. Joshi and Resham Bhalla
}

Received:11.11.2012

Revised:19.12.2012

Accepted: 14.02.2013

\begin{abstract}
Living organisms live within a narrow zone of tolerance of climatic conditions. Fresh water fish Ophiocephalus unmourilius is found in Chanakapur dam of Girna river in Kalwan (M.S.). The fish showed irreversible changes in carbohydrates, proteins and Ascorbic acid content when exposed to cold stress. Due to cold stress glycogen and protein content of brain and muscles tissue show considerable increase where as liver tissue show decreasing trend. Similarly ascorbic acid content show increasing trend in brain but considerable decrease in liver and muscular tissue was observed.
\end{abstract}

Keywords: Cold stress, biochemical constituents, Ophiocephalus unmourilius, Girna river

\section{Introduction}

Most plants and animals live within relatively narrow range of temperature, extending from about $0^{0} \mathrm{C}$ to $45^{\circ} \mathrm{C}$. Decrease in ambient temperature brings about irreversible changes in protein, lipid, carbohydrate and vitamin ' $\mathrm{C}$ ' content of animal body (Somero and Hochachka, 1976). In fresh water the incidences of exposure of aquatic organisms to decreased temperature are quite frequently observed. It is well known that, in Chanakapur area of Kalwan (M.S.) heavy winters result in decrease in temperature up to $2^{0} \mathrm{C}$ to $4^{0} \mathrm{C}$. This sever cold definitely bring out some characteristic changes in metabolism of the organisms, but detailed studies of this area were still lacking.Present investigation is an attempt to estimate the quantitative turnover in carbohydrate, protein and vitamin ' $C$ ' (Ascorbic acid) content in the tissue of the body of fresh water fish Ophiocephalus unmourilius. The study is mainly concentrated on the protein, glycogen and ascorbic acid content of brain, liver and muscles, before and after cold stress.

\section{Material and Methods}

The fish Ophiocephalus unmourilius were collected from Chanakapur dam of Girna river (M.S.) and

\section{Author's Address}

Department of Zoology, L.V. H. A.S.C. College, Panchvati,

Nashik.(M.S.)

E-mail: Anandjoshi71@gmail.com brought to the laboratory. The fishes of similar weight (9-10 gms.) and size (7-10 cm long) were selected and acclimatized to laboratory conditions. The physicochemical characteristics of aquarium water are shown in Table 1.1. In actual experimental work, the fishes were divided into groups of five. The experimental group, fishes were exposed to cold stress $\left(4^{0} \mathrm{C}\right.$ and $\left.8^{0} \mathrm{C}\right)$ for 30 minutes in a refrigerator with thermostat. (Count down starts after the temperature of water becomes of desired value.) After 30 minutes, the fishes were quickly scarified and dissected to take out brain, liver and muscles. These fresh tissues were used to estimate proteins by Lowery et. al. method (1951), glycogen was estimated by modified Anthrone reagent method and ascorbic acid content was estimated by conventional 2,6 di nitrophenol endophenol method. Same procedure was used to estimate proteins, glycogen and ascorbic acid from control group. The data obtained was analyzed statistically by students ' $t$ ' test, keeping level of significance, $\mathrm{p}<0.05$. Each result reported was an average of three analyses.

\section{Results and Discussion Glycogen}

After cold stress (exposure to $4^{0} \mathrm{C}$ and $8^{0} \mathrm{C}$ ) it can be seen that, accumulation of glycogen in muscles $(25.32 \pm 0.10 \mathrm{mg} / \mathrm{gm}$ and $20.0 \pm 0.10 \mathrm{mg} / \mathrm{gm})$ and brain $(13.70 \pm 0.10 \mathrm{mg} / \mathrm{gm}$ and $13.70 \pm 0.10 \mathrm{mg} / \mathrm{gm})$ 
occurs, where as the glycogen in liver is decreased $(16.29 \pm 0.10 \mathrm{mg} / \mathrm{gm}$ and $54.80 \pm 0.09 \mathrm{mg} / \mathrm{gm})$ as shown in the table 1.2, 1.3 and figure 1.1 and 1.4. This may be due to cold stress, which may have severely depleted the liver glycogen reserves. Decrease in liver glycogen of Ophiocephalus unmourilius might be due to process of glycolysis during exposure period. There may be the higher energy demands during cold exposure. Moranta et.al., 1982 reported similar results in Salmo gairdneri.

\section{Proteins}

After cold stress, changes in the protein level, in various tissues i.e. brain $(279 \pm 0.10 \mathrm{mg} / \mathrm{gm}$ and $273.0 \pm 0.6 \mathrm{mg} / \mathrm{gm})$ and muscles $(23.75 \pm 0.90 \mathrm{mg} / \mathrm{gm}$ and $27.8 \pm 0.5 \mathrm{mg} / \mathrm{gm}$ ) showed an increasing trend and decrease in liver proteins $(83.4 \pm 0.10 \mathrm{mg} / \mathrm{gm}$ and $80.31 \pm 0.5 \mathrm{mg} / \mathrm{gm}$ ) as shown in the table 1.2 , 1.3 and figure 1.2 and 1.5. The increased protein content of brain and muscles after cold stress is opined by Someru and Hochachka, 1976; de Vries, 1980; Hew et.al. 1980. This suggests that proteins in all tissues are responsive to low temperatures.

Ascorbic acid

Ascorbic acid level, after cold stress increase in brain $(0.45 \pm 0.08 \mathrm{mg} / \mathrm{gm}$ and $0.50 \pm 0.08 \mathrm{mg} / \mathrm{gm})$ and decrease in liver $(0.21 \pm 0.05 \mathrm{mg} / \mathrm{gm}$ and $0.30 \pm 0.05 \mathrm{mg} / \mathrm{gm})$ and muscles $(0.16 \pm 0.05 \mathrm{mg} / \mathrm{gm}$ and $0.26 \pm 0.05 \mathrm{mg} / \mathrm{gm})$ as shown in table 1.2 and 1.3 and figure 1.3 and 1.6. From this it can be possible that the increase in ascorbic acid in brain may act as antioxidant by trapping the oxygen radicals $\left(\mathrm{O}^{-}\right.$and $\left.\mathrm{OH}^{-}\right)$, which results due to metabolic reaction during stress (Das, 1988). It is a well established fact that in collagen formation ascorbic acid is a external reductant which is required for conversion of proline to hydroxyproline (Leninger, 1982; Das 1988). A similar mechanism is also possible in Ophiocephalus unmourilius.

Table 1.1 Physico-chemical characteristic of water of aquarium, at $25^{0} \mathrm{C}$

\begin{tabular}{|l|l|l|}
\hline $\mathbf{p H}$ & Hardness as $\mathrm{CaCO}_{3} \mathbf{( p p m )}$ & Dissolved oxygen (ppm) \\
\hline $7.5 \pm 0.6$ & $120.0 \pm 8.0$ & $6.2 \pm 1.2$ \\
\hline
\end{tabular}

Table 1.2: For $4^{0} \mathrm{C}$, effect of cold stress on biochemical constituents of Ophiocephalus unmourilius (values as $\mathrm{mg} / \mathrm{gm}$ weight wet tissue) (Values represented $\pm(n=4) \mathrm{p}, 0.05$ )

\begin{tabular}{|l|l|l|l|l|}
\hline Tissue & & Glycogen & Protein & Ascorbic acid \\
\hline \multirow{3}{*}{ Brain } & Control & $4.032 \pm 0.09$ & $196.0 \pm 0.15$ & $0.20 \pm 0.05$ \\
\cline { 2 - 5 } & Expt. & $13.70 \pm 0.10$ & $279.0 \pm 0.10$ & $0.45 \pm 0.08$ \\
\hline \multirow{2}{*}{ miver } & Control & $80.64 \pm 0.09$ & $100.0 \pm 0.13$ & $0.53 \pm 0.07$ \\
\cline { 2 - 5 } & Expt. & $61.29 \pm 0.10$ & $83.40 \pm 0.12$ & $0.21 \pm 0.05$ \\
\cline { 2 - 5 } & Control & $4.67 \pm 0.09$ & $7.80 \pm 0.10$ & $0.33 \pm 0.08$ \\
\cline { 2 - 5 } & Expt. & $25.32 \pm 0.10$ & $23.75 \pm 0.90$ & $0.16 \pm 0.05$ \\
\hline
\end{tabular}

Table 1.3: For $8^{0} \mathrm{C}$, effect of cold stress on biochemical constituents of Ophiocephalus unmourilius (values as $\mathrm{mg} / \mathrm{gm}$ weight wet tissue) (Values represented $\pm(n=4) \mathrm{p}, 0.05)$.

\begin{tabular}{|l|l|l|l|l|}
\hline Tissue & & Glycogen & Protein & Ascorbic acid \\
\hline Brain & Control & $5.33 \pm 0.09$ & $212.5 \pm 0.50$ & $0.18 \pm 0.05$ \\
\cline { 2 - 5 } & Expt. & $13.70 \pm 0.10$ & $273.0 \pm 0.60$ & $0.50 \pm 0.08$ \\
\hline \multirow{2}{*}{ Liver } & Control & $72.50 \pm 0.09$ & $112.0 \pm 0.50$ & $0.45 \pm 0.07$ \\
\cline { 2 - 5 } & Expt. & $54.80 \pm 0.09$ & $80.31 \pm 0.50$ & $0.30 \pm 0.05$ \\
\hline \multirow{2}{*}{ muscles } & Control & $4.83 \pm 0.07$ & $9.06 \pm 0.60$ & $0.42 \pm 0.07$ \\
\cline { 2 - 5 } & Expt. & $20.00 \pm 0.10$ & $27.80 \pm 0.50$ & $0.26 \pm 0.05$ \\
\hline
\end{tabular}


Figure 1.1: For $4^{0} \mathrm{C}$, effect of cold stress on Glycogen content of Ophiocephalus unmourilius (values as $\mathrm{mg} / \mathrm{gm}$ weight wet tissue) (Values represented $\pm(n=4) \mathrm{p}, 0.05)$ in different tissues.

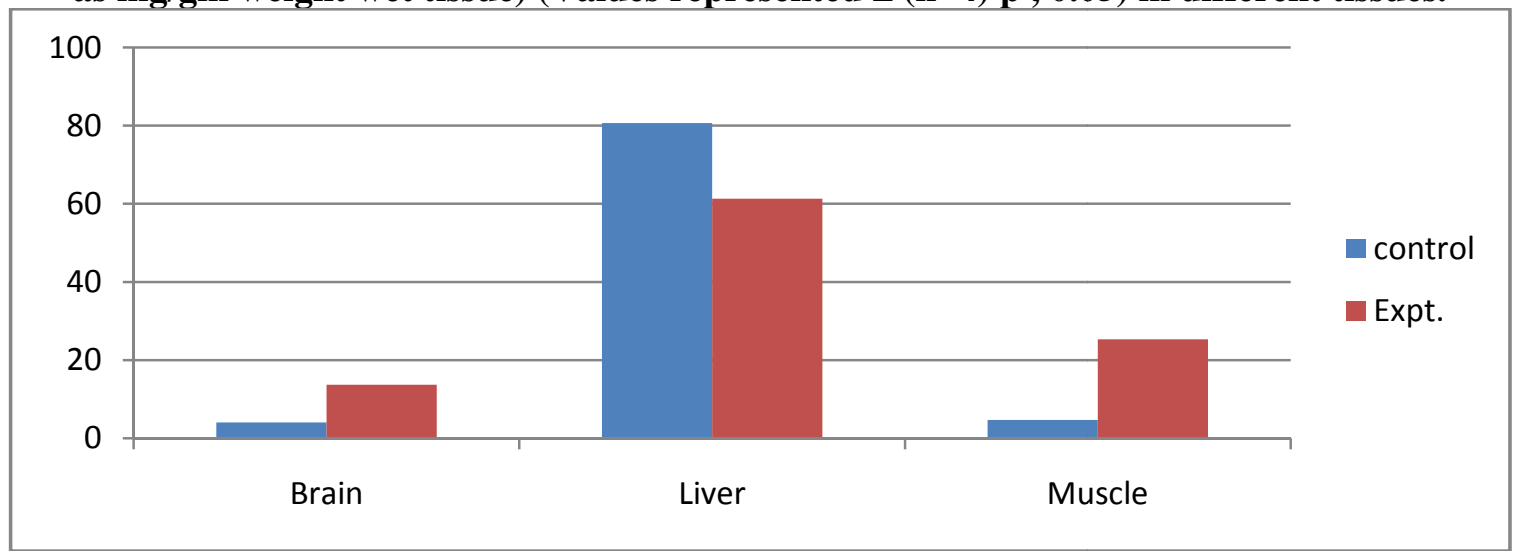

Figure 1.2:For $4^{0} \mathrm{C}$, effect of cold stress on Protein content of Ophiocephalus unmourilius (values as $\mathrm{mg} / \mathrm{gm}$ weight wet tissue) (Values represented $\pm(n=4) \mathrm{p}, 0.05)$ in different tissues.

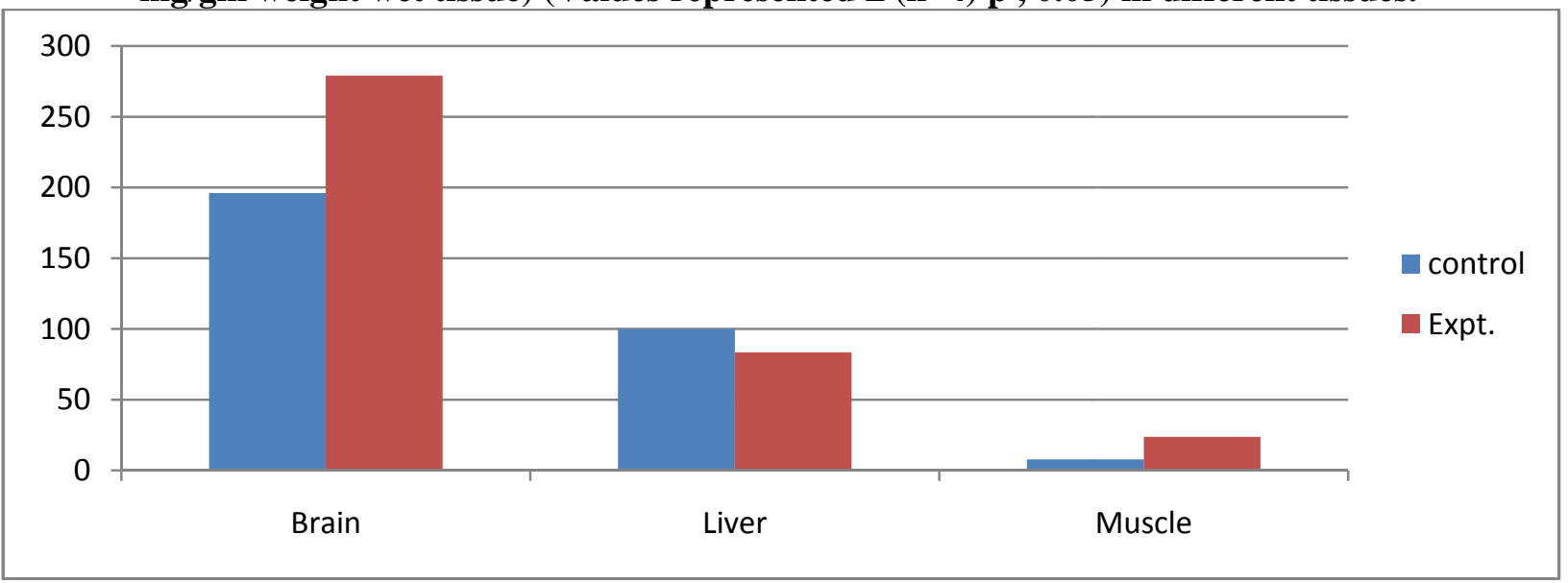

Figure 1.3: For $4^{0} \mathrm{C}$, effect of cold stress on Ascorbic acid content of Ophiocephalus unmourilius (values as $\mathrm{mg} / \mathrm{gm}$ weight wet tissue) (Values represented $\pm(n=4) \mathrm{p}, 0.05)$ in different tissues.

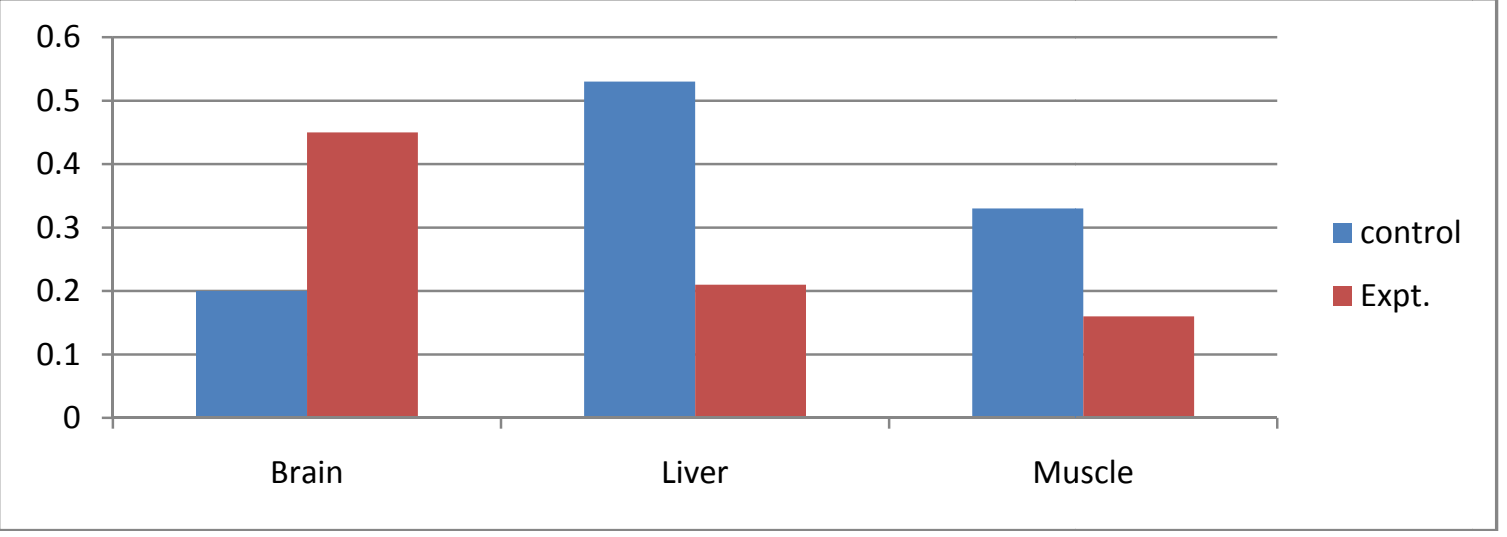


Figure 1.4:For $8^{0} \mathrm{C}$, effect of cold stress on Glycogen content of Ophiocephalus unmourilius (values as $\mathrm{mg} / \mathrm{gm}$ weight wet tissue) (Values represented $\pm(\mathrm{n}=4) \mathrm{p}, 0.05)$ in different tissues.

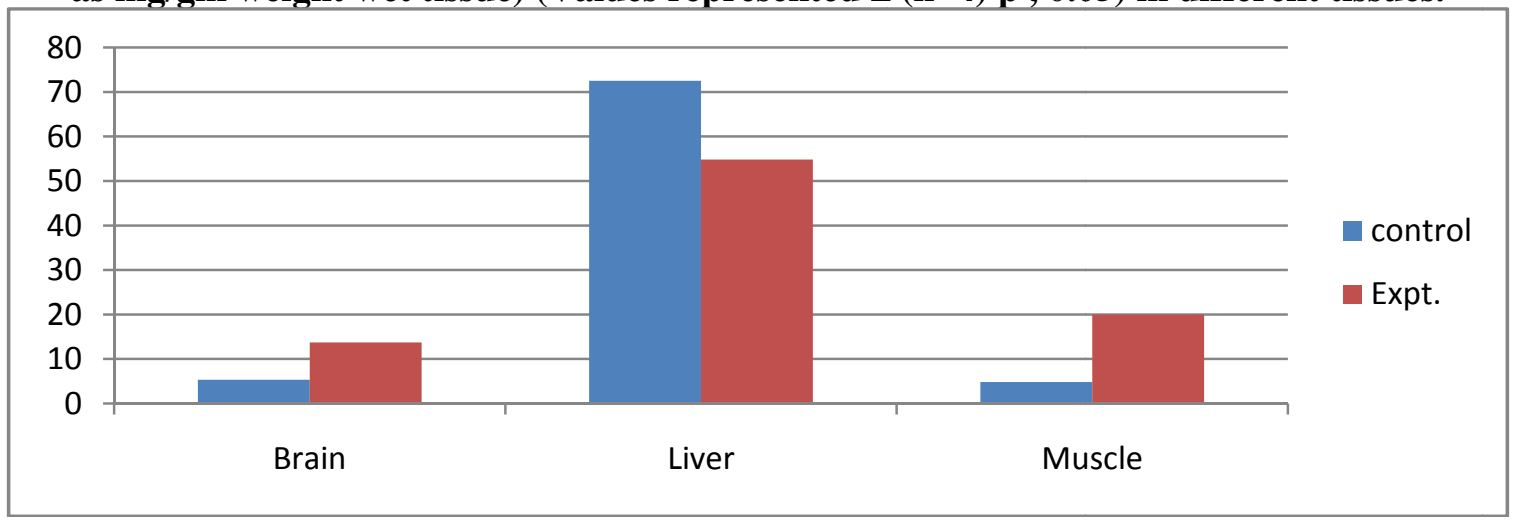

Figure 1.5: For $8^{0} \mathrm{C}$, effect of cold stress on Protein content of Ophiocephalus unmourilius (values as $\mathrm{mg} / \mathrm{gm}$ weight wet tissue) (Values represented $\pm(n=4) \mathrm{p}, 0.05)$ in different tissues.

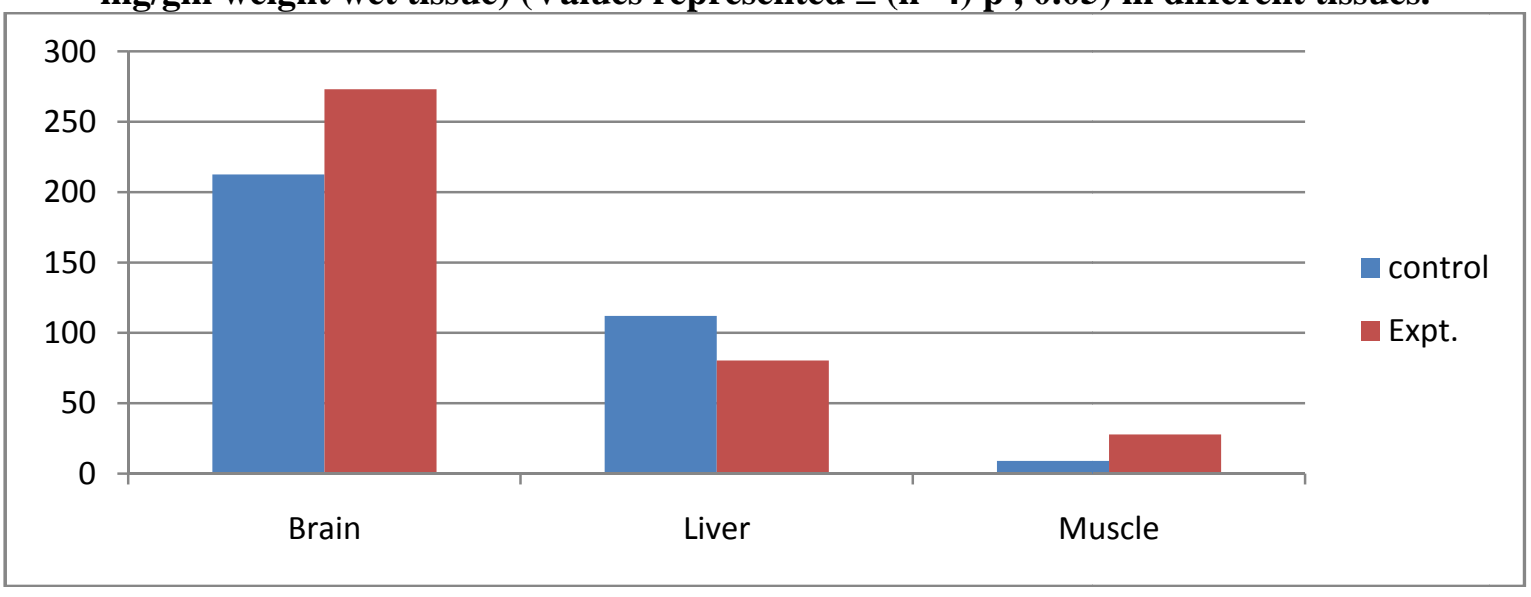

Figure 1.6: For $8^{0} \mathrm{C}$, effect of cold stress on Ascorbic acid content of Ophiocephalus unmourilius (values as $\mathrm{mg} / \mathrm{gm}$ weight wet tissue) (Values represented $\pm(n=4) \mathrm{p}, 0.05)$ in different tissues.

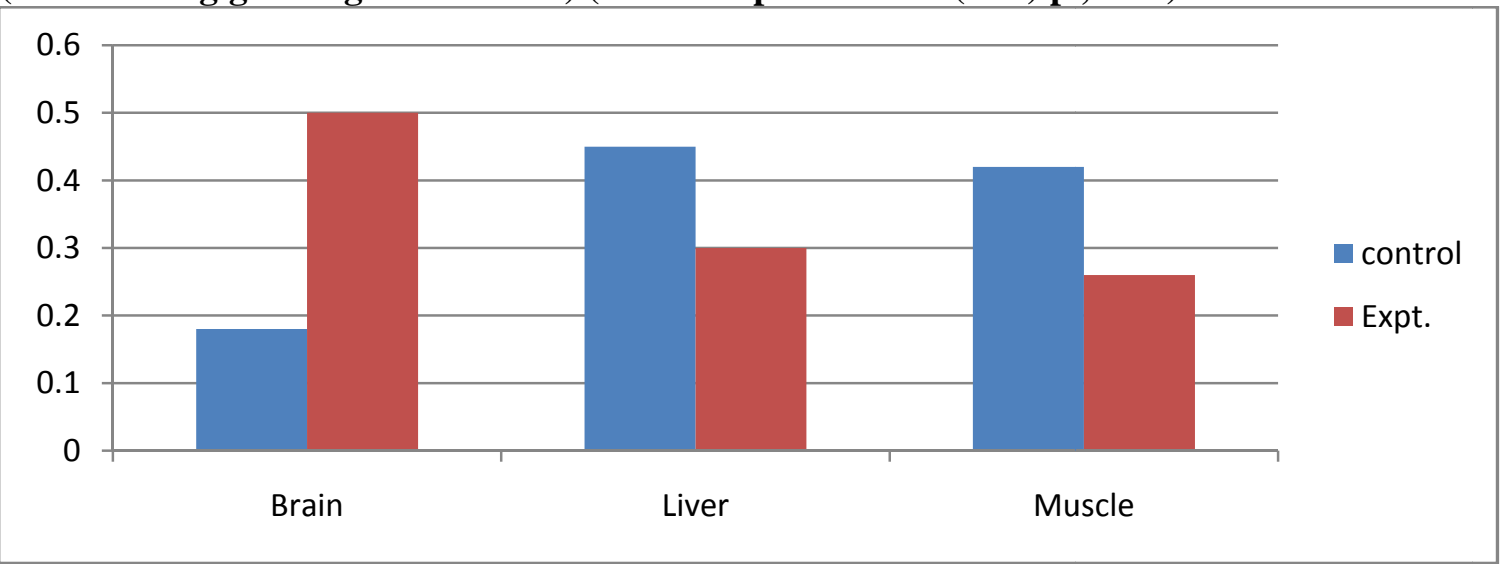


Effect of cold stress on biochemical

\section{References}

De Vries, A.L., 1971. Glycoprotein's as biological antifreezents in Antarctic fishes. Science; 172:1152-1155.

De Vries, A.L., 1971. Freezing resistance in fishes. In Hoar and Randall, 6: 157-190.

De Vries, A.L., 1980. Biological antifreezents and survival in freezing environment. In R. Gills (Ed)., Pergamon Press, Oxford. pp: 583-603.

Das, D., 1988.Biochemistry, $5^{\text {th }}$ ed. Academic Press Publishers.

Hew, C.L.; G.L. Fletcher and V.S. Ananthanarayanan, 1980. Antifreeze proteins from the shorthorn Sculpin. Can.J.Biochem.58: 377-383.

Kushner, D.J. (ed.) 1978. Microbial env. in low temp., Academic Press., London. Pp: 465.

Leninger, A.L., 1982. Principles of biochemistry, Worth publishers, USA.
Morantha, P; Faus, N.J; Pezza Palamo and Sanchez Medina, F., 1982. Effects of stress on muscle and liver glycogen phosphorylase in rainbow trout, Comp. Biochem. Physiol. 72 b. pp: 421-425.

Oliver H. Lowery; Nira J. Rosebrough; A. Lewis, Farr and Rose J. Randall., 1951. Protein measurement with folin phenol reagent. J. Biol. Chem. 193. pp: 265-275.

Seifer, S.; Dayton, S.; Navic, B. and Munrwy, G.R., 1950. Estimation of glycogen with anthrone reagent. Arch. Biochem. Biophys., 25(1): 191-200.

Somero, G.N. and P.W. Hochachka., 1976. Biochemical adaptations to temperature. In Newell., pp: 125-190.

Umminger, B.L., 1971. Pattern of osmoregulation in F.W. fishes at temperature near freezing., Physiol. Zool. 44: 20-27.

Umminger, B.L., 1972. Physiological studies on super cooled kill fish, J. Exp. Zool., 181: 217-222. 